\title{
Estimation of the Total Number of Nucleated Cells in the Blood-Forming Organs by Cell-Counting Method
}

\author{
By \\ Kazuhiko Awaya \\ Department of Anatomy, Yamaguchi Medical School, Ube
}

During the past few years, a cell-counting method has gradually been developed in this laboratory to estimate quantitatively the total number of nucleated cells in the thymolymphatic tissues and the bone marrow in the albino rats (A w a y et al., $1960 ; 1962$ ). The technic, and the results obtained by its use, form the subject of the present report.

\section{Material and Technic}

All the observations were made on young healthy male albino rats, between $200 \mathrm{~g}$ to $230 \mathrm{~g}$ in weight, of 4 or 5 months of age and of the Wistar strain. They were maintained on a uniform diet, consisting of unpolished rice, pressed barley and dried small sardine with a small amount of cod liver oil and minerals, supplemented once a week with green vegetables. Water was given ad libitum. For several years our work has been done with male Wistar strain albino rats of constant body weight (O s o g o e and A w a y a, 1958; M o n d e n, 1959; O k a d a, 1960; O s o g o e, 1960). It is essential that the test animals are under as nearly identical nutritional state as possible and of constant body weight. We have come to regard as unreliable any work on quantitative measurements of blood forming tissues in which due attention has not been paid in selecting animals of constant body weight, since it is frequently observed that the cellular density or the rate of cell multiplication may vary, to a considerable degree, in proportion to the nutritional condition and the monthly or even weekly age of the animal. 


\section{The technic for thymolymphatic organs.}

Immediately after sacrificing the animals, thymus, mesenteric lymph nodes and spleen are excised and weighed. A portion of each, weighing about $20 \mathrm{mg}$ is placed in a small glass stoppered vial containing $2 \mathrm{~mm}^{3}$ of $\mathrm{N} / 4 \mathrm{HCl}$ solution. After having placed the tissues in the solution for 2 to 3 hours, they are finely dispersed by the aid of the tips of two fine needles, yielding a homogeneous suspension of nuclei separated from the cytoplasm. This is our modification of the technic described by $\mathrm{Chr}$ istensen in 1950 . The volume of the $\mathrm{N} / 4 \mathrm{HCl}$ solution used as diluent is thus approximately 100 times the weight of the tissues. This degree of dilution is relevant to hemocytometer count. When less than $2 \mathrm{~mm}^{3}$ of the dilution is used the suspension becomes too cellular for accuracy of hemocytometer counting, and when more than $2 \mathrm{~mm}^{3}$ is used some question of homogenity of the suspension is likely to arise.

The sample of suspension of nuclei thus prepared is drawn up into two leucocyte pipettes (previosuly checked for precision), diluted with Tür k's fluid, and the number of nuclei counted in a checked $\mathrm{Neubauer}$ hemocytometer, counting 4 squares of each chamber and 2 chambers for each sample. Thus, the number of nuclei per $\mathrm{mm}^{3}$ of suspension is counted, from which the total number of nucleated cells per mg of fresh tissue of each organ is calculated. By multiplying this cellular number by the weight of each organ the total number of nucleated cells in each organ can be computed.

\section{The technic for bone marrow.}

For the determination of bone marrow cellularity a modification was adopted from the methods described by $\mathrm{Fruhm}$ a n and $\mathrm{G}$ ordon (1953) and $Y$ of $f$ e $y$ (1956). The bone marrow is taken out from the main shaft of the right femur of young adult albino rats. The carefully weighed marrow sample, about $20 \mathrm{mg}$, is placed into a small vial containing $2 \mathrm{~mm}^{3}$ of homologous serum or commercial human plasma and uniformly suspended by drawing the marrow up and down with a robber-nippled pipette. Samples of the suspension are drawn into two white blood cell pipettes, diluted with $\mathrm{T} u ̈ \mathbf{r}$ 's fluid, and hemocytometer counts made of the nucleated cells. As the medium for diluting the bone marrow, commercial human plasma yielded results not inferior to those obtained with homologous serum. For this reason, the author has mainly employed the human plasma in this study. In the case of the bone marrow also, it was found 
that the degree of dilution suitable for a cell count was aprroximately 100 times the weight of the bone marrow. The number of nucleated cells per $\mathrm{mg}$ of the fresh bone marrow (cellular density) may be obtained easily from the formula:

$$
\text { Cellular density }=\frac{\begin{array}{c}
\text { Total number of nucleated cells in the } \\
\text { specimen of the bone marrow used }
\end{array}}{\text { Weight of the specimen of bone marrow used }}
$$

In the previous report (A w a y a et al. 1960), the cellular density was expressed as the number of nucleated cells per $\mathrm{mm}^{3}$ of tissues. The specific gravity of bone marrow is estimated to be 1.028 by $\mathrm{Mech}$ a nik (1926). The number of cells per $\mathrm{mg}$ can thus be regarded practically as synonymous to that per $\mathrm{mm}^{3}$. By multiplying this value by the total amount of bone marrow the entire number of nucleated cells contained in bone marrow of the whole body can be computed. Regarding the quantity of bone marrows of albino rats, Fa i r m a n and $\mathrm{C}$ or ner (1934) gave 2.71-3.23 g, K in d r e d (1942) a value of $1.18 \mathrm{~cm}^{3}, \mathrm{H}$ a sh i moto (1953) and $\mathrm{W}$ a t a $\mathrm{nabe}$ (1955) gave $1.65 \mathrm{~g}$ as the weight or volume per $100 \mathrm{~g}$ body weight. The present author has employed the valuation of $\mathrm{Hash}$ imoto and $W$ at a n a be. Since the fat marrow was included in their estimation, these figures may requires some correction. But the relative amount of fat marrow being unknown, their material was tentatively assumed to contain the red marrow only.

\section{Results and Discussion}

\section{Thymolymphatic tissues.}

The results of experiments on thymus, mesenteric lymph nodes and spleen of 15 rats are shown in Table 1 . The mean and the standard error of the number of nucleated cells per $\mathrm{mg}$ of fresh tissues of each organ were $(3.64 \pm 0.085) \times 10^{6}$ cells in the thymus, $(2.34 \pm 0.094) \times 10^{5}$ cells in the mesenteric lymph nodes and $(1.47 \pm$ $0.101) \times 10^{6}$ cells in the spleen, from which the total number of nucleated cells in the whole of each organ was computed to be $(899 \pm$ $83.6) \times 10^{6},(718 \pm 65.7) \times 10^{6}$ and $(958 \pm 63.4) \times 10^{4}$, respectively.

Comparison of the above figures of the total nucleated cells of each organ with the previously reported results of computation of DNA (M o n d e $n$ 1959) shows that both methods yield results that agree fairly closely, although the figures from the present study are 
Table 1. Total number of nucleated cells in the thymus, of mesentric lymph nodes, spleen and bone marrow of young adult albino rats weighing around $200 \mathrm{~g}$. (Average of 15 rats). (Mean \pm standard error)

\begin{tabular}{l|c|c|c}
\hline \multirow{2}{*}{ Organ } & $\begin{array}{c}\text { Organ weight } \\
(\mathrm{mg})\end{array}$ & \multicolumn{2}{|c}{ Total number of nucleated cells } \\
\cline { 3 - 4 } & per mg $\left(\times 10^{-6}\right)$ & per organ $\left(\times 10^{-6}\right)$ \\
\hline Thymus & $247 \pm 19.6$ & $3.64 \pm 0.085$ & $899 \pm 83.6$ \\
Mesenteric & $307 \pm 22.8$ & $2.34 \pm 0.094$ & $718 \pm 65.7$ \\
lymph nodes & $652 \pm 60.6$ & $1.47 \pm 0.101$ & $958 \pm 63.4$ \\
Spleen & $3416 \pm 61.1$ & $2.00 \pm 0.08$ & $6922 \pm 398.7$ \\
\hline
\end{tabular}

Table 2. Comparison of the values of the total number of nucleated cells in the chief thymolymphatic organs obtained by the present method with those obtained by the DNA determinations. (Mean \pm standard error)

\begin{tabular}{c|c|c}
\hline Method & $\begin{array}{c}\text { Value obtained by the } \\
\text { present method }\left(\times 10^{-6}\right)\end{array}$ & $\begin{array}{c}\text { Value obtained by DNA } \\
\text { Determination } \\
\text { (Monden, 1959) }\left(\times 10^{-6}\right)\end{array}$ \\
\hline Thymus & $\begin{array}{c}899 \pm 83.6 \\
(36.2 \%) *\end{array}$ \\
Mesenteric & $718 \pm 65.7$ & $1,094 \pm 114$ \\
lymph node & $(35.4 \%) *$ & $71.6 \%)^{*}$ \\
Spleen & $958 \pm 63.4$ & $(50.1 \%)^{*}$ \\
$(25.6 \%) *$ & $1,375 \pm 189$ \\
\hline
\end{tabular}

* Figures in parenthesis indicate the calculated values of the coefficient of variation.

generally lower than those of DNA method (Table 2). However, it should be noted that the values obtained by the present method show smaller individual deviation and lower coefficient variation than those shown in DNA method in any lymphoid organ. This fact speaks for considerable dependability of the cell counting method. The DNA method is based on the constancy of average DNA content per nucleus and requires skill in chemical technic. It is so cumbersome in its execution that its wide use for routine work by technicians in histological laboratories can hardly be expected at the present time. On the contrary, the method we have presented here is very simple and can be used successfully even by the most inexperienced technicians. 
Bone marrow.

Results of the determination experiment performed simultaneously on the right femoral marrow of the same animals are shown in Table 1. The mean and the standard error of the number of nucleated cells per $\mathrm{mg}$ of fresh bone marrow is $(2.00 \pm 0.08) \times 10^{6}$, from which the total number of nucleated cells in the bone marrow of the whole body was computed to be $(6922 \pm 398.7) \times 10^{8}$. This computation was made on the assumption that the weight of the total bone marrow was 1.65 per cent of the body weight. In the previous paper (A w a a et al. 1960), the corresponding values in 41 rats were reported to be $(1.81 \pm 0.05) \times 10^{6 *}$ and $(5840 \pm 161.4) \times 10^{6}$, respectively.

These results are accepted on the assumption that the marrows of the long bones constituting the major part of the bone marrow of the whole body would exhibit the equal degree of hematopoietic activity, and therefore the numbers of nucleated cells in these marrows of different bones are likely to equal per unit mass weight. Analysis of the data shows that this assumption is correct (Table 3).

Table 3. Density of cell population of bone marrow of various sites.

(Mean \pm standard error)

\begin{tabular}{|c|c|c|c|c|c|c|}
\hline $\begin{array}{l}\text { Animal } \\
\text { group }\end{array}$ & \multicolumn{2}{|c|}{10 animals } & \multicolumn{4}{|c|}{7 animals } \\
\hline Site & $\begin{array}{l}\text { right } \\
\text { femoral }\end{array}$ & $\begin{array}{c}\text { left } \\
\text { femoral }\end{array}$ & $\begin{array}{l}\text { right } \\
\text { femoral }\end{array}$ & $\begin{array}{l}\text { right } \\
\text { tibial }\end{array}$ & $\begin{array}{l}\text { right } \\
\text { humeral }\end{array}$ & $\begin{array}{l}\text { left femoral, } \\
\text { tibial and } \\
\text { humeral } \\
\text { combined }\end{array}$ \\
\hline $\begin{array}{l}\text { No. of } \\
\text { nucleated } \\
\text { cells } \\
\text { per mg } \\
\left(\times 10^{-6}\right)\end{array}$ & $1.91 \pm 0.069$ & $1.94 \pm 0.077$ & $1.94 \pm 0.048$ & $1.83 \pm 0.061$ & $1.83 \pm 0.062$ & $1.73 \pm 0.072$ \\
\hline
\end{tabular}

Compared with the previously reported values on the bone marrow of albino rats, the above results would fall about midway between the high and low values (Table 4).

Finally some mentions must be made on problem common to both thymolymphatic and bone marrow tissues.

As previously mentioned, the quantity of $\mathrm{N} / 4 \mathrm{HCl}$ solution or

* This value is expressed as the number of cells per $\mathrm{mm}^{8}$ of marrow tissues. It is practically the same as the value of $(1.76 \pm 9.05) \times 10^{6}$ cells per $\mathrm{mg}$. 
Table 4. Density of cell population of bone marrow tissue of rats estimated by different authors. (Mean \pm standard error)

\begin{tabular}{l|c|c}
\multicolumn{1}{c|}{ Author } & $\begin{array}{c}\text { Number of } \\
\text { animals }\end{array}$ & $\begin{array}{c}\text { Number of nucleated cells } \\
\text { per } \text { m }^{3} \text { or mg }\left(\times 10^{-6}\right)\end{array}$ \\
\hline Kindred (1942) & 8 & 1.98 \\
Mota (1951): & 15 & $1.46 \pm 0.04$ \\
Fruhman \& Gordon (1953) & 5 & $2.40 \pm 0.11$ \\
Fruhman \& Gordon (1955) & 9 & $2.52 \pm 0.06$ \\
Meineke \& Crafts (1956) & 9 & $1.75 \pm 0.17$ \\
Meineke \& Crafts (1956) & 5 & $2.00 \pm 0.16$ \\
A waya et al. (1960) & 41 & $1.81 \pm 0.05$ \\
Table 1, This paper & 15 & $2.00 \pm 0.08$ \\
\hline
\end{tabular}

human plasma used as diluent must be approximately 100 times the weight of the tissue segment used. Therefore, in order to maintain an appropriate count when less than $10 \mathrm{mg}$ of tissue segment has been removed, the volume of the diluting fluid must be reduced to $1 \mathrm{~mm}^{3}$. This is especially true when the test animals less than 2 weeks of age are being employed, since these animals show immature growth of blood-forming tissues and often it is impossible to obtain more than $10 \mathrm{mg}$ of the mesenteric nodes or bone marrow.

The differences in cellular density according to the differences in monthly or weekly age must also be considered. According to $\mathrm{B} \mathrm{urke}$ and $\mathrm{H}$ a r r s (1959), the number of nucleated cells in the bone marrow of the albino rats is $(2.060 \pm 0.227) \times 10^{6}$ per $\mathrm{mm}^{3}$ on the 7 th day of postnatal growth, it increases rapidly up to a value of $(3.062 \pm 0.368) \times 10^{6}$ in 6 weeks after birth, but thereafter declines sluggishly to level off at $(2.310 \pm 0.158) \times 10^{6}$ in 50 weeks. Thus, an appreciable variation in the cellular density is discernible in the bone marrow during the course of postnatal growth. This is true also in the thymolymphatic tissues (A w a y a, unpublished). Accordingly the author has tried to sidestep an error due to such variation by using animals of constant body weight and age as much as possible.

On surveying the data obtained in this laboratory during the past few years, it was found that the numbers of nucleated cells per unit weight have tended to rise somewhat (see Table 4). We attribute this to a general improvement in technic, together with a reduction in the number of damaged cells.

The defects inherent to the present method were discussed else- 
where (A w a y a et al. 1962). In spite of these defects, the method does seem to give us consistent results and we believe that it offers definite usefulness of studing hemocytopoiesis of blood-forming organs in the albino rat.

\section{Summary}

A cell-counting method is described for estimation of the number of nucleated cells in the thymolymphatic tissues and bone marrow. The principle of the method consists of preparing the cell suspension of each tissue and of making hemocytometer count of nucleated cells. Data obtained from 15 young adult albino rats weighing around $200 \mathrm{~g}$ are summarized in Table 1.

\section{Acknowledgement}

The author wishes to express his thanks to Prof. Bunsuke O s o g o e of Okayama University who, had headed this department till March 1961, for his constant interest, guidance and encouragement in this investigation.

\section{References}

A w a y a, K., H. F u ji i, Y. T a n a ka and O k a d a 1960. Estimation of total number of nucleated cells in the bone marrow of young adult albino rats. Arch. hist. jap., $18: 473-477$.

A wa ya, K., M. Oda, S. A be and M. Yoshimura 1962. A simple method for evaluation of total cellular number in the thymolymphatic organs. Arch. hist. jap., 22 203-207.

Burke, W. T. and C. $\mathrm{H}$ ar ris 1959. Total cell counts of bone marrow of normal albino rats from 1 to 50 weeks of age. Blood, $14: 409-414$.

$\mathrm{Ch}$ istensen, S. 1950 . Method for determination of the mitotic activity in haemopoietic tissues. Acta anat., $10: 233-237$.

$\mathrm{F}$ a i r m a n, E. and G. W. Corner 1934. The bone-marrow volume of the albino rat. Anat. Rec., 60 : 1-4.

Fruh ma n, G. J. and A.S. Gordon 1953. Quantitative evaluation of total cellular numbers of bone marrow. Anat. Rec., 117: 603.

F r u h m a n, G. J. and A. S. Gord on 1955. A quantitative study of adrenal influences upon the cellular elements of bone marrow. Endocrinology, $57: 711-718$.

H a s h i m oto, M. 1953. Histological structure of the bone marrow. Symposium on Hematology, 5 : 114-172. (Japanese)

$\mathrm{K}$ in d re d, J. E. 1942. A quantitative study of the hemopoietic organs of young adult albino rats. Amer. J. Anat. $71: 207-243$.

Mechanik, N. 1926. Untersuchung über das Gewicht des Knochenmarkes des Men- 
schen. Z. Anat. EntwGesch., 79 : 58-99.

Meineke, H. A. and R. C. C rafts 1956. A study of the anemia induced by hypophysectomy and that induced by combined thyroidectomy and adrenalectomy in Wistar, Long-Evans and Sprague-Dawley rats. Anat. Rec., $124: 47-66$.

Monden, Y. 1959. Quantitative evaluation of total cellular number and cellular density in the thymolymphatic organs of young adult albino rats by means of DNA determination. Okajimas Fol. anat. jap., 32 : 193-206.

Mot a, I. 1951. A method for quantitative estimation of mast cells in the bone marrow of the rat. Blood, $6: 81-83$.

$\mathrm{Okada}, \mathrm{M} .1960$. A quantitative study on the rate of cell production in the bone marrow of young mature albino rats. Okajimas Fol. anat. jap., 35: 375-402.

O sog oe, B. and K. A w a y a 1958. Turnover of cell population in blood and bloodforming tissue. Acta haem. jap., 21 : 408-418.

Os og oe, B. 1960. A quantitative study on the relationship of lymphocytopoiesis to granulo- and erythrocytopoiesis in young mature albino rats. Bull. Yamaguchi Med. School, $7:$ 171-179.

$\mathrm{W}$ a t a $\mathrm{n}$ a b e, S. 1955. The weight of bone marrow. J. Kyushu Hem. Soc., $5:$ 132-157. (Japanese with English abstract, p. 157)

Y of $\mathrm{fe} y, \mathrm{~J} . \mathrm{M}$. 1956. The mobilization and turnover times of cell populations in blood-forming tissue. J. Histochem. Cytochem., 4 : 516-530. 